\title{
Norte e sul, centro e periferia: a projeção cartográfica como estratégia discursiva do poder colonial
}

North and south, center and periphery: the cartographical projection as a discursive strategy from the colonial power

Norte y sur, centro y periferia: la proyección cartográfica como estrategia discursiva del poder colonial

\author{
Daniel Perico Graciano ${ }^{1}$ \\ Universidade Federal de São Carlos \\ dani_p.graciano@hotmail.com \\ Livia Beatriz Damaceno ${ }^{2}$ \\ Universidade Federal de São Carlos \\ liviabea22@gmail.com
}

\begin{abstract}
RESUMO: Realizamos uma breve reflexão acerca da projeção Mercator, a projeção cartográfica mais utilizada no mundo desde o século XVI, como um enunciado comandado por interesses político-econômicos que regem as relações de poder desde o período de expansão colonial europeia até a atualidade. As divisões norte e sul, centro e periferia, se manifestam como função enunciativa de um dispositivo estratégico do poder colonial, a partir de arranjos de linhas de forças que instauram programas de verdade. As reflexões presentes neste artigo têm por pretensão realizar uma análise arquegenealógica pautada no pensamento de Michel Foucault $(1996 ; 1997 ; 2014)$, a fim de apreender os arranjos que emergem das relações de poder expressas na historicidade do enunciado em questão.
\end{abstract}

Palavras-chave: Análise do Discurso; Cartografia; Dispositivo.

\begin{abstract}
We have made a brief reflection on the Mercator projection, the most used cartographic projection in the world since the 16th century, and as a statement led by political-economic interests that govern power relations from the period of European colonial expansion to the present day. The divisions between north and south, center and periphery, manifest themselves as an enunciative function of a strategic device of the colonial power, from arrangements of forces that establish programs of truth. The reflections presented in this article are intended to carry out an archegenealogical analysis based on the thinking of Michel Foucault $(1996,1997,2014)$, in order to apprehend the arrangements that emerge from the relations of power expressed in the historicity of the statement in question.
\end{abstract}

Keywords: Discourse Analysis; Cartography; Apparatus.

\footnotetext{
1 Mestrando do Programa de Pós-Graduação em Linguística da Universidade Federal de São Carlos (PPGL/UFSCar).

2 Mestranda do Programa de Pós-Graduação em Linguística da Universidade Federal de São Carlos (PPGL/UFSCar)
} 
RESUMEN: Realizamos una breve reflexión acerca de la proyección Mercator, la proyección cartográfica más utilizada en el mundo desde el siglo XVI, como un enunciado comandado por intereses político-económicos que rigen las relaciones de poder desde el período de expansión colonial europea hasta la actualidad. Las divisiones norte y sur, centro y periferia, se manifiestan como función enunciativa de un dispositivo estratégico del poder colonial, a partir de arreglos de líneas de fuerzas que instauran programas de verdad. Las reflexiones presentes en este artículo tienen por pretensión realizar un análisis arquegéalógico pautado en el pensamiento de Michel Foucault (1996; 1997; 2014), con el fin de aprehender los arreglos que emergen de las relaciones de poder expresadas en la historicidad del enunciado en cuestión.

Palabras clave: Análisis del Discursos; Cartografía; Dispositivo. 


\section{Introdução}

O corpo se junta à terra que ele pisa. E progressivamente, dessa maneira, ele não está na paisagem: ele é a paisagem. (GROS, 2011, p. 89)

Este trabalho consiste em uma breve reflexão acerca da projeção cartográfica canônica do globo terrestre, a projeção Mercator, partindo da hipótese deque ela funciona como um indicativo de um poder colonial. O mapa é um desenho estático, já a cartografia é constitutiva e constituinte em relação à paisagem, ela acompanha seus movimentos, é uma ação antropofágica, já que devora toda linguagem que afeta as paisagens psicossociais que lhe são contemporâneas. As marcas de cada um dos elementos que constituem uma cartografia, aqueles que foram por ela "devorados", são indícios que denunciam os acontecimentos que a afetaram acrescentando direções, expandindo e metamorfoseando as formas de concepção do mundo.

O mapa é um enunciado, enquanto função que autoriza a existência de signos que têm uma potencialidade, uma virtualidade, que atualiza a existência de outros enunciados (FOUCAULT, 1996). Qual é o centro do mundo? Quais são suas periferias? O que está em cima? O que está embaixo? Tudo isso fica a critério do sujeito enunciador, que constrói uma visão das coisas a partir de condições que tornam possível sua realização. Mas que condições são essas? Quais as epistemes, quais as formações discursivas que regulam seus enunciados?Para responder a essas questões, delimitamos nosso objeto de análise: a representação cartográfica canônica e padrão do globo terrestre (o "mapa-mundi”), segundo idealizada por Gerardus Mercator (1569), ainda hoje utilizada em praticamente todas as formas de apresentações oficiais, didáticas, informacionais, etc., do mundo.

Além da representação gráfica/logarítmica de Mercator, apresentaremos algumas funções contemporâneas que dela variam, para isso, o que nos interessa é historicizar os regimes que criam, por meio da representação de mundo criada por meio da projeção Mercator, as dimensões que operam nos sujeitos e nos objetos. Não se trata, portanto, de historicizar os sujeitos e os objetos, mas de realizar uma busca dos acontecimentos que propiciaram as condições de emergência dos regimes (os processos, os devires e as práticas discursivas). Sendo assim, os acontecimentos não devem ser confundidos com os acontecidos.

São duas as dimensões do dispositivo que integram o campo do saber: a linhas de enunciabilidade e as linhas de visibilidade (DELEUZE, 2005). Ou seja, regimes de linguagens, no caso uma linguagem visual, e os regimes corpóreos (materiais e imateriais) que 
constroem as formas de saber. Sendo assim, é por meio de duas formalizações diferentes e heterogêneas que os saberes se materializamno mapa. Pretendemos, dessa forma, problematizar o mapa enquanto monumento, questionar os saberes que ali se encontram, as verdades ali impressas, para então saber qual a forma de poder que o realiza e sob quais condições. A projeção cartográfica em questão é aqui observada como um conjunto de "relações de força que se entrecruzam, que remetem umas às outras, convergem ou, ao contrário se opõem" (FOUCAULT, 1997, p. 71).

Imagem 1 - A projeção Mercator

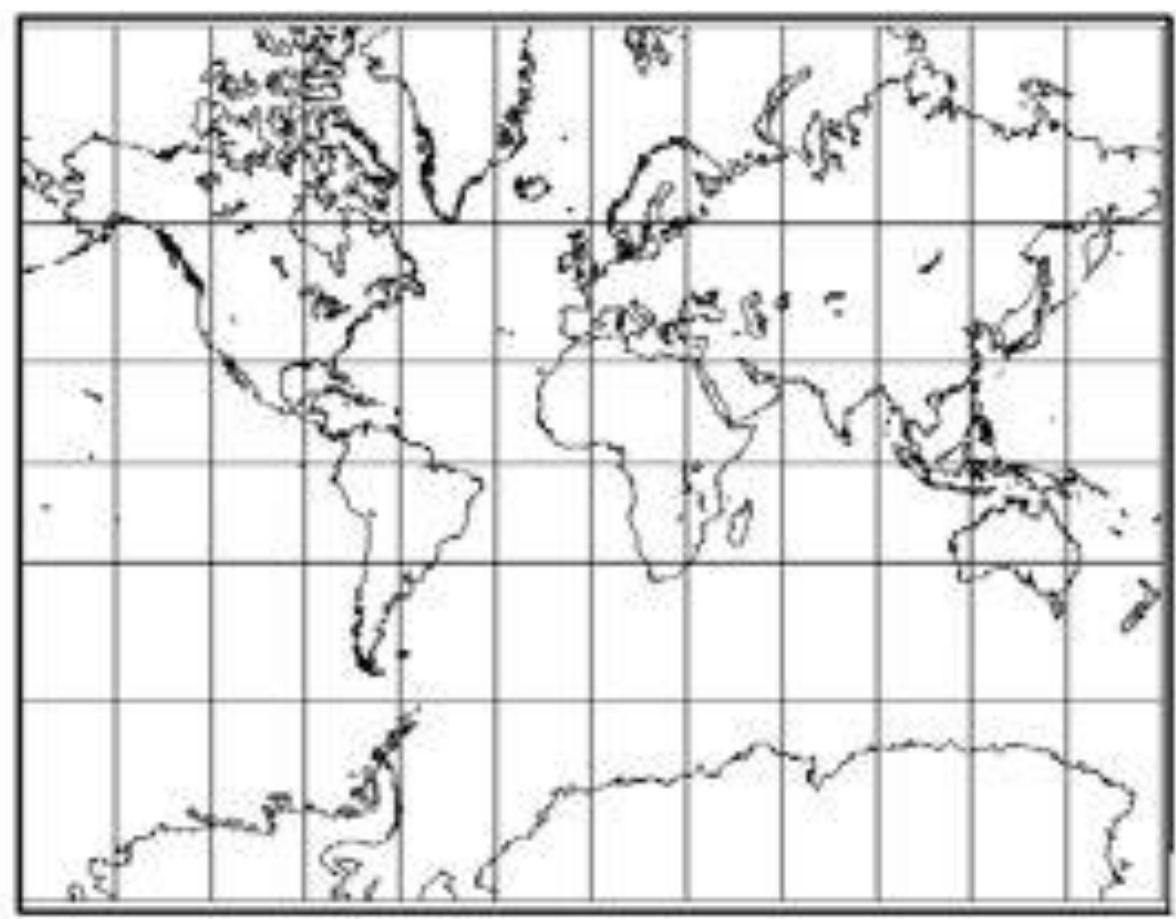

Fonte: < mercator.ufc.br>.

\section{Norte e Sul: a metafísica da colonização}

A emergência de instituições como a plantation e a colônia coincide com o longo período em que se esboça e, por fim, se afirma uma nova razão governamental no ocidente (MBEMBE, 2018, p. 144)

Falar de cartografia é remeter ao dispositivo. O dispositivo é uma máquina de percepção dos fluxos (devires, linhas de força), que nos liberta da tradição do olhar para as dicotomizações, como, por exemplo, sujeito e objeto, construídas e formalizadas pela máquina concreta da enunciação, 
[...] um conjunto decididamente heterogêneo que engloba discursos,instituições, organizações arquitetônicas, decisões regulamentares, leis,medidas administrativas, enunciados científicos, proposições filosóficas,morais, filantrópicas. Em suma, o dito e o não dito são os elementos do dispositivo. O dispositivo é a rede que se pode estabelecer entre estes elementos... [e entre estes] existe um tipo de jogo, ou seja, mudanças de posição, modificações de funções, que também podem ser muito diferentes, [cuja finalidade] é responder a uma urgência. (FOUCAULT, 2014, p.244-245)

Se o mapa divide o mundo, por um lado entre norte e sul e, por outro, entre centro e periferia, ele compõe arranjos a partir de linhas de força que criam determinados programas de verdade que comportam funções político-econômicas bem delimitadas. A separação metafísica de mundos entre superior e inferior impede um foco nos agenciamentos de fluxos, a partir das crenças nos substratos que estruturam a relação entre subjetivação e objetivação. A estrutura é uma espécie de representação, que relaciona sujeito e objeto. Trata-se de uma prática ascética (askésis) que, para Foucault são exercícios “disponíveis, recomendados, até mesmo obrigatórios, ou pelo menos utilizáveis pelos indivíduos em um sistema moral" (FOUCAULT, 2010, p. 374), isso é o que para Nietzsche constitui uma inversão de valores, descrita na alegoria que segue:

Para longe de todos os sóis? Não caímos continuamente? Para trás, para os lados, para a frente, em todas as direções? Existem ainda 'em cima' e 'embaixo'? Não sentimos na pele o sopro do vácuo? Não se tornou ele mais frio? Não anoitece eternamente? Não temos que acender lanternas de manhã? Não ouvimos o barulho dos coveiros a enterrar Deus? Não sentimos o cheiro da putrefação divina? Também os deuses apodrecem! Deus está morto! (NIETZSCHE, 2005, p. 147)

A separação de dois mundos, hemisfério norte e hemisfério sul, é a distinção metafísica entre superior (norte) e inferior (sul) que redunda na hierarquização ascética de um dos polos envolvidos nessa concepção dicotômica de mundo. Daí resulta a construção dos sujeitos e de seus objetos, objetos metafísicos: o sujeito do sul tem por objeto a própria condição metafísica e(ou) ontológica de vir-a-ser o sujeito do hemisfério norte, trata-se de um objetivo, um ideal de perfeição que deve ser alcançado. Mas como se dão os arranjos discursivos na construção desses programas de verdade?

O corpo adestrado tem uma única referência: a norma. Esse corpo aprende e apreende saberes selecionados para que a manutenção do próprio adestramento se realize. Uma das produções do poder é o homem e, além disso, sua hierarquização naturalizada, isto é, 
normalizada, por múltiplos tipos de saber, um deles é a forma como se concebe e retrata o espaço que compartilhamos.

As noções espaciais se dão a partir da percepção tridimensional que temos do espaço físico (altura, largura e profundidade),por meio de tal concepção criamos metáforas que refletem juízos de valor em relação ao espaço físico: enunciados como "ele está pra baixo hoje" ou "desta vez ele foi muito baixo" se contrapõem a enunciados como "está tudo em cima" ou "ele é acima da média"; noções como "superior" e "inferior" regem uma boa parte da forma como enquadramos os acontecimentos. Portanto, o que está "em baixo" tende a ser associado a um valor negativo, enquanto o que está "em cima" tende ao positivo.

A história da moral cristã é a história dessa divisão, já que os ideais ascéticos traduzem por si só a vontade de nada manifesta em um lugar ideal. As terras de "canibais" e “cinocéfalos" descritas por Colombo nos Diários da Descoberta da América (1998) remetiam facilmente à criação de Dante Alighieri (o inferno cristão) que data do início do século XIV. Na Divina Comédia vemos alusões ao canibalismo (ALIGHIERI, 1998, p. 219-220):

\footnotetext{
"Depois, mais do que a dor pode o jejum". Sua fala aí encerrou e, c' o olhar torto, Retomou crânio mísero co' os dentes Assim como em seu osso um cão absorto.
}

Também vemos alusões aos cinocéfalos por uma vasta literatura produzida durante a idade média, cuja principal é descrita e confirmada por Catimpré no décimo quarto tomo de seu Liber de Monstruosis Hominibus Orientis (Livro dos homens monstruosos do Oriente) (1227). Da mesma forma que o cristianismo criou o inferno, o hemisfério norte cria o

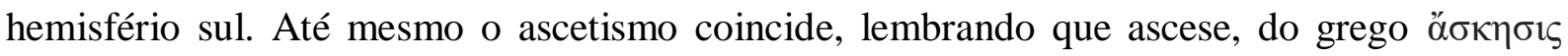
(askésis), diz respeito não só a uma elevação espiritual, mas a metáfora de "elevar-se" por si só indica uma subida, um ato de partir para cima, para um objetivo idealizado.

Por volta de 1451, o tráfico intercontinental de escravizados do Congo teve início. No ano do nascimento de Colombo, os povos capturados foram traficados para o continente Europeu. Se o poder necessita de corpos para se manifestar, é, a partir daí, que os corpos africanos serão por ele marcados. A lenda da divisão norte/sul é a lenda da superioridade racial, do nascimento de uma episteme racista: a lenda do capitalismo. Por meio de uma bula papal, a Bula Dum, o papa Nicolau V concederia, no ano seguinte (1452), ao rei de Portugal Afonso V, o direito de exploração, escravização e colonização das terras não-cristãs: 
[...] outorgamos por estes documentos presentes, com a nossa Autoridade Apostólica, permissão plena e livre para invadir, buscar, capturar e subjugar sarracenos e pagãos e outros infiéis e inimigos de Cristo onde quer que se encontrem, assim como os seus reinos, ducados, condados, principados, e outros bens e para reduzir as suas pessoas à escravidão perpétua (BOXER, 1877, p. 44).

Quarenta e um anos depois, no dia 12 de outubro de 1492, Colombo chega ao lugar que hoje chamamos de "Bahamas", financiado pelos "reis católicos". Em decorrência desse acontecimento, o papa Alexandre VI expande a autorização de escravização aos povos das Américas em sua Bula Inter Caetera (do latim "outros trabalhos), no dia 4 de maio de 1493 (HAYES, 1998). De acordo com Mbembe (2018, p. 122): "no argumento colonial, a raça sempre aparecia ao mesmo tempo como uma matriz material, uma instituição simbólica e um componente psíquico da política e da consciência imperiais".

No que diz respeito ao argumento colonial que toma como matriz o fator racial na concepção global entre norte e sul, até o início do século XVII o tráfico atlântico de escravizados não envolvia a América britânica, já que foi somente a partir do tratado de 1707 que as 13 colônias britânicas foram formadas à norte. Esse hiato de mais ou menos duzentos anos foi suficiente para estabelecer a divisão norte/sul.

Imagem 2 - Rota do tráfico de escravizados

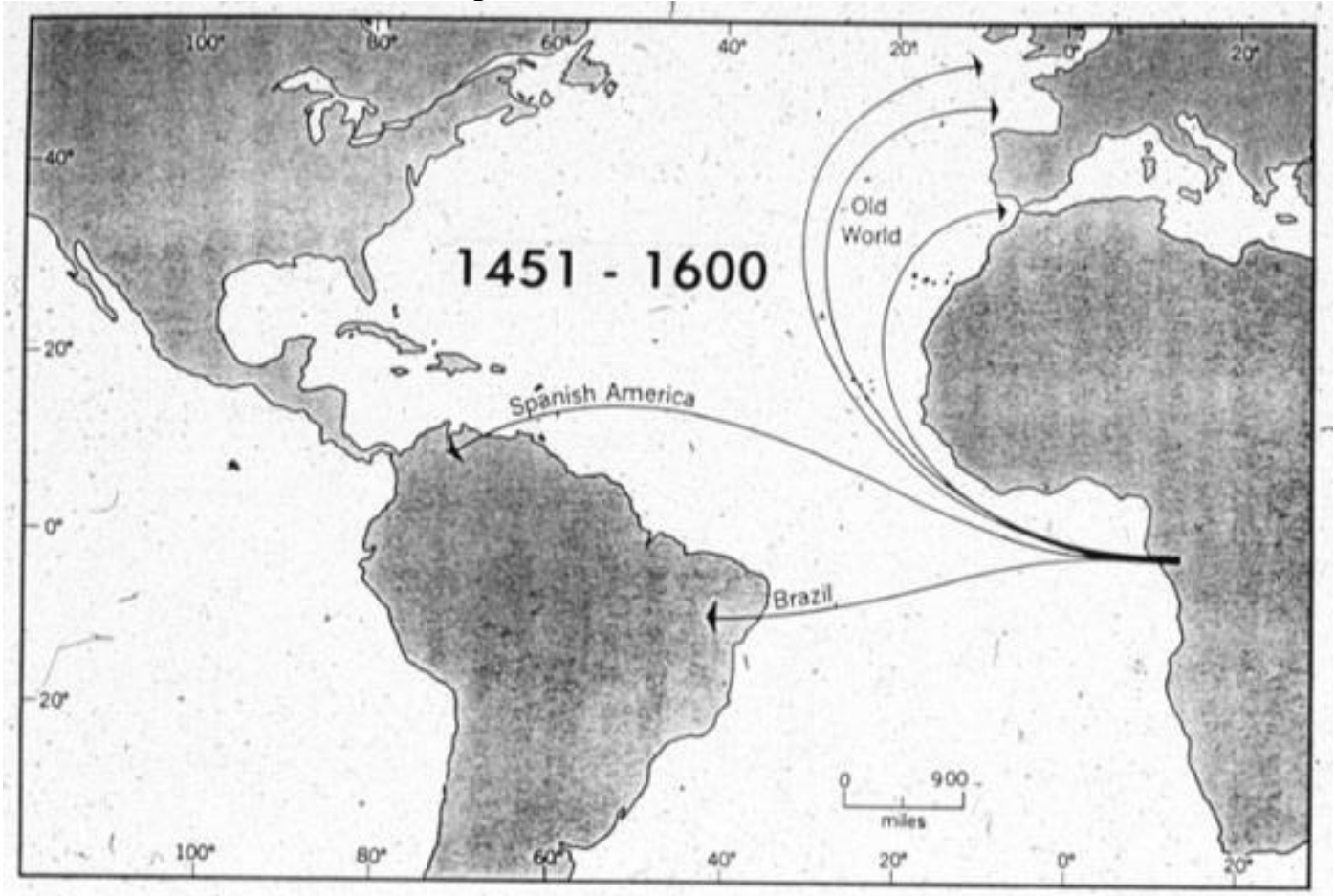

Fonte: <scielo.br>. 
Como podemos ver na representação cartográfica abaixo, o fluxo quantitativo de escravizados não se divide com o crescimento de destinos nas Américas, mas se multiplica.

Imagem 3 - Rota do tráfico de escravizados

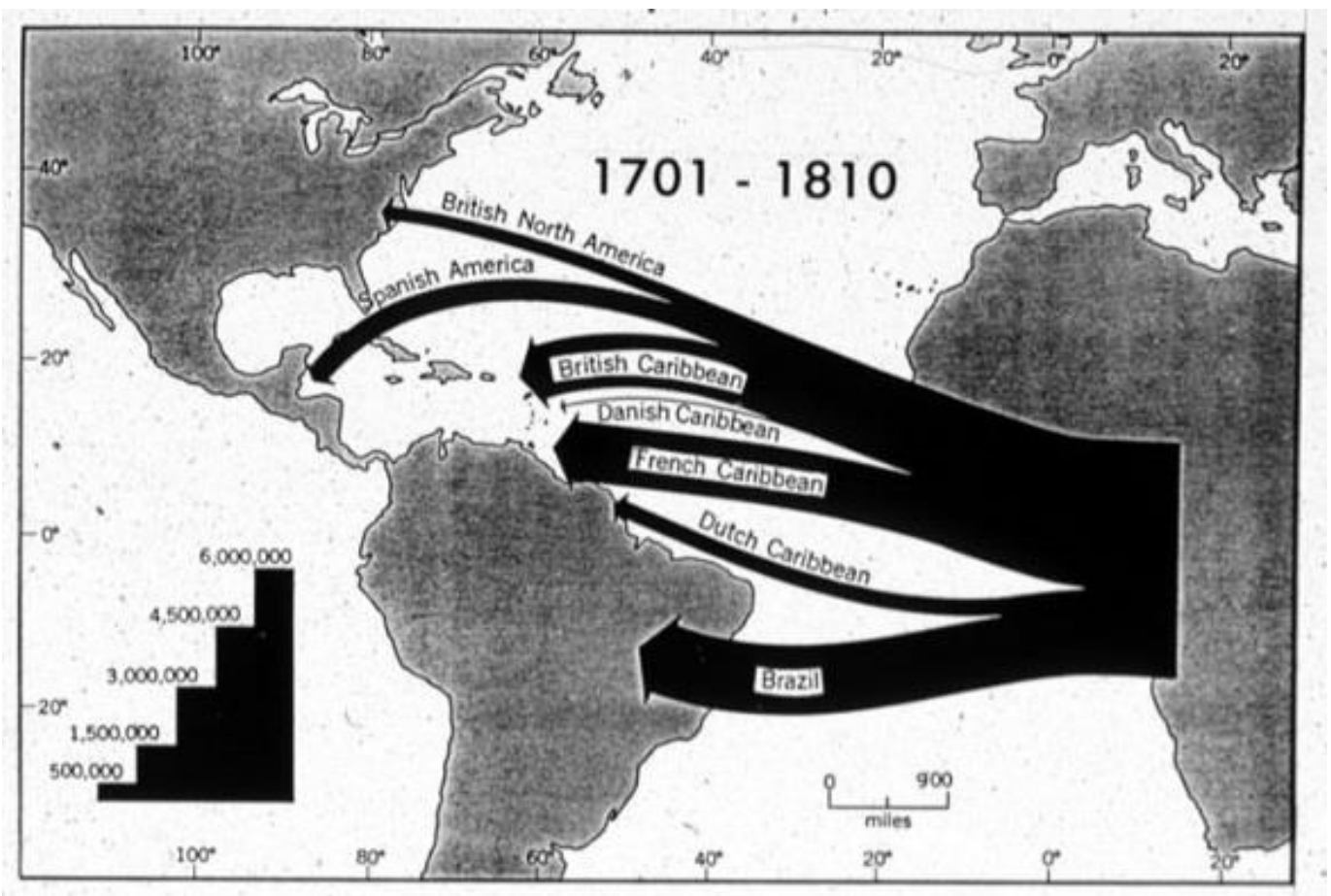

Fonte: <scielo.br>.

A escravização massiva dos povos africanos e sul-americanos é determinante na divisão meridional aqui denunciada. Outro fator que colabora para a perpétua colonização do Sul pode ser sua "independência" tardia em relação à América do Norte, também decorrente da escravização dos corpos do Sul. Foi no século XVIII que as 13 colônias norte-americanas se tornaram uma nação independente, enquanto as colônias latinas do Sul só começaram a se "libertar" de maneira definitiva a partir do século XIX, sendo que até a presente data algumas ainda não conseguiram sua autonomia.

Voltando ao século XVI, percebe-se que é a partir daí que já se começa a desenhar a configuração meridional. O reino de Portugal construiu nessa época a primeira grande rede global, instalando postos militares e mercantis ao longo do litoral atlântico da América do Sul, em parte do litoral africano e em parte do litoral asiático, traçando as linhas estratégicas de poder que compõem seu dispositivo colonial. Porém, no século XVII, a expansão portuguesa começa a ser acuada pelos holandeses, que tomam as bases estratégicas lusitanas (Java, Sumatra, Malaca), o que leva o poder colonial português a se concentrar no Atlântico Sul, 
concentrando a exploração no tráfico de escravizados, que, como podemos ver no mapa abaixo, se intensifica consideravelmente em relação ao período anterior:

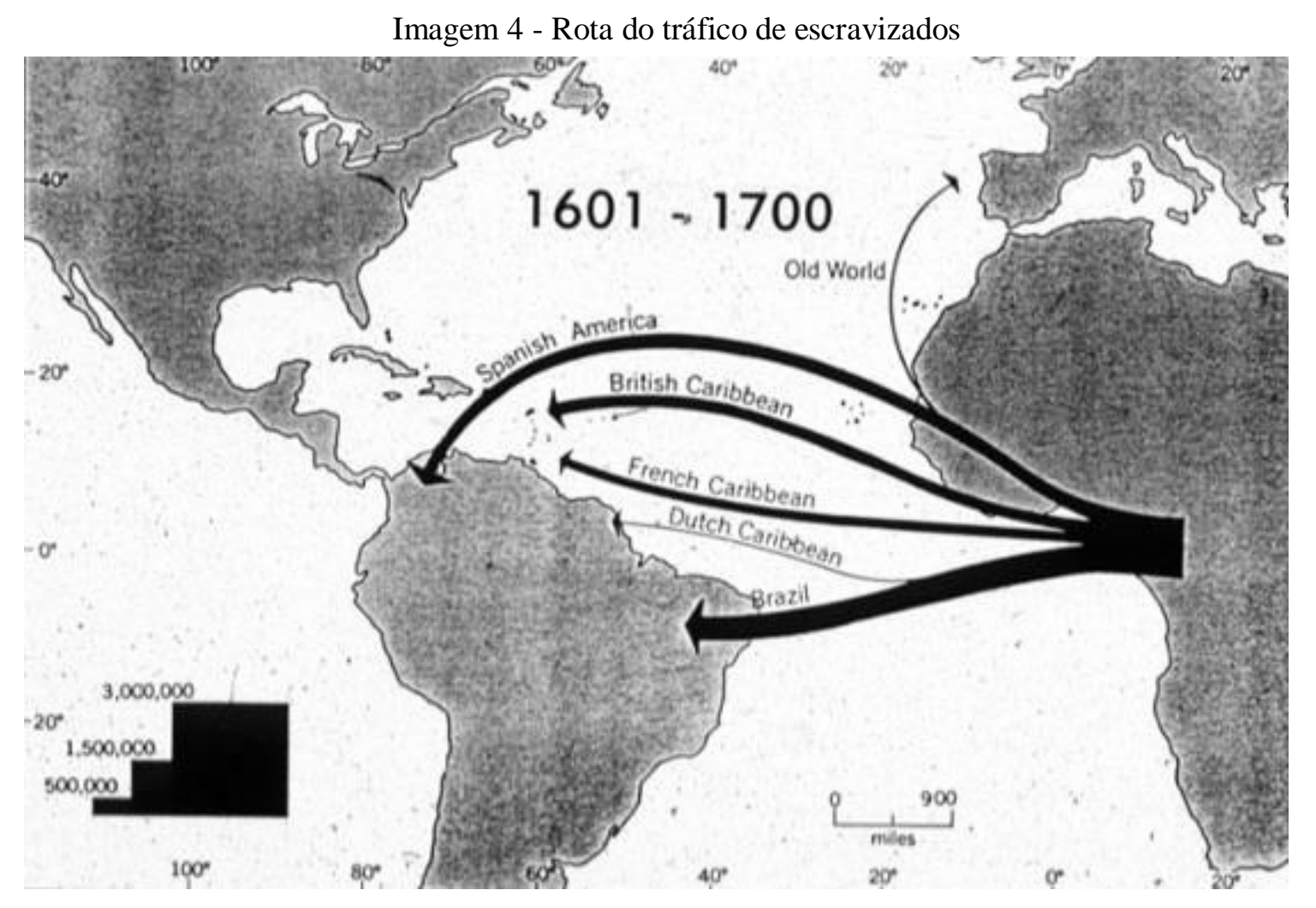

Fonte: <scielo.br>.

A herança da política colonialista lusitana se manifesta ainda após a proclamação da independência, com as investidas brasileiras pela expansão da bacia platina, no final do século XIX, e as anexações de territórios vizinhos já na República Velha.

Na segunda metade do século XX, evidenciaram-se as demandas econômicas pósfordistas, impondo uma oscilação palindrômica do capital que, entre hemisfério norte e hemisfério sul, instaura uma lógica unilateral de exploração monetária. O capitalismo acionarial e sua plena atividade de precarização é a forma de poder que, a partir do decênio de 1970, toma corpo na divisão imaginária dos hemisférios. Com a desvinculação do dólar em relação ao padrão do ouro em 1971 e, em decorrência, com a crise do petróleo em 1973, a soberania dos territórios do sul global deixa definitivamente de existir. A virada monetarista neoliberal operada durante a crise fiscal de Nova Iorque, entre 1974 e 1975, decreta distribuições funcionais em que o hemisfério sul deve adotar uma forma de produção que atenda às demandas da máquina financeira do hemisfério norte por meio da conversão da composição orgânica do capital em trabalhador em tempo integral e essa é mais uma das 
formas como esse poder se exerce nos corpos. O geógrafo estadunidense Mike Davis explica que

[...] entre 1974 e 1975, o Fundo Monetário Internacional, seguido pelo Banco Mundial, mudou o seu enfoque dos países industriais desenvolvidos para o Terceiro Mundo, que cambaleava sob o impacto dos preços cada vez mais altos do petróleo. Ao aumentar passo a passo os seus empréstimos, o FMI ampliou aos poucos o alcance das "condicionalidades" coercitivas e "ajustes estruturais" que impunha aos países seus clientes (DAVIS, 2006, p. 156).

A queda do pacto de Varsóvia, resultante da declaração soviética n. 124-H, do dia 26 de dezembro de 1991, resulta no governo totalitário das forças da OTAN que coloniza todo o globo. A falácia da globalização evidencia a desigualdade entre os hemisférios, pois há imperativos como a "dívida", já várias vezes paga, contraída pelos países da América do Sul, América Central, África e parte do sul asiático, em sua relação de subordinação ao Banco Mundial e ao FMI, que injeta e concentra cada vez mais dinheiro no Norte.

Sendo assim, as condições que tornam possível a emergência dos enunciados que discriminam a concepção norte-sul, é a invenção de uma concepção metafísica que se baseia em uma semântica que engloba um campo de oposição entre os substantivos superioridade (norte) e inferioridade (sul). Enquanto as formações discursivas que regulam o enunciado (mapa) e seu campo associado, ainda em relação à oposição norte-sul, em uma formação discursiva escravagista, já que os sujeitos do Sul são sobrecodificados por significantes coletivos que os marcam como corpos impossibilitados de constituir uma imagem e um cuidado de si, em que não há uma possibilidade de autonomia da própria produção discursiva. Importante esclarecer que as estratégias e táticas de resistência que propiciam as fugas evidentes do dispositivo colonial (e.g. os quilombos, as insurreições, etc.), i.e., os corpos que não se deixam capturar, não são o foco da presente discussão.

\section{Centro e periferia: a geometria da dominação}

A rainha Elisabeth I da Inglaterra nasceu em Greenwich e governou de 1558 a 1603. A monarca adotou como causa principal de seu reinado a intensificação dos incentivos ao poder marítimo britânico, para que fossem também intensificadas suas campanhas coloniais (FERNANDES, 2015). A voracidade do poder colonial inglês evidencia a necessidade de uma projeção cartográfica como a de Mercator, que, a partir de Greenwich, enquanto ponto 
equidistante que ocupava o paradoxal "centro" de uma esfera, colocava a terra de Elisabeth I como ponto de referência absoluto. Foi graças a esse mesmo mapa que, por exemplo, o vicealmirante do reino da Inglaterra, Francis Drake, pôde circumnavegar o mundo entre 1577 e 1580 em seu projeto colonial/escravagista.

No entanto, a emergência da concepção cristalizada advinda da projeção cartográfica britânica resulta de um estado de forças agonísticas, um combate com as condições desfavoráveis em concorrência nas campanhas coloniais europeias do século XVI. As principais forças em guerra contra a Inglaterra eram, além da "corrida" colonial, as potências religiosas: o protestantismo pragmaticamente adotado por Henrique VIII (pai de Elisabeth I) vinha cada vez mais desencadeando tensões em relação a grande potência católica, a Espanha. Tal embate acirraria ainda mais as lutas e disputas pela colonização do maior número possível de territórios. O investimento militar da coroa britânica acabou derrotando as armadas espanholas, o que, sem dúvidas, colabora para a cristalização de nosso objeto, como um saber que se projeta sobre seus antagonistas (ANDERSON, 1995).

Imagem 5 - O meridiano Greenwich no "centro do mundo"

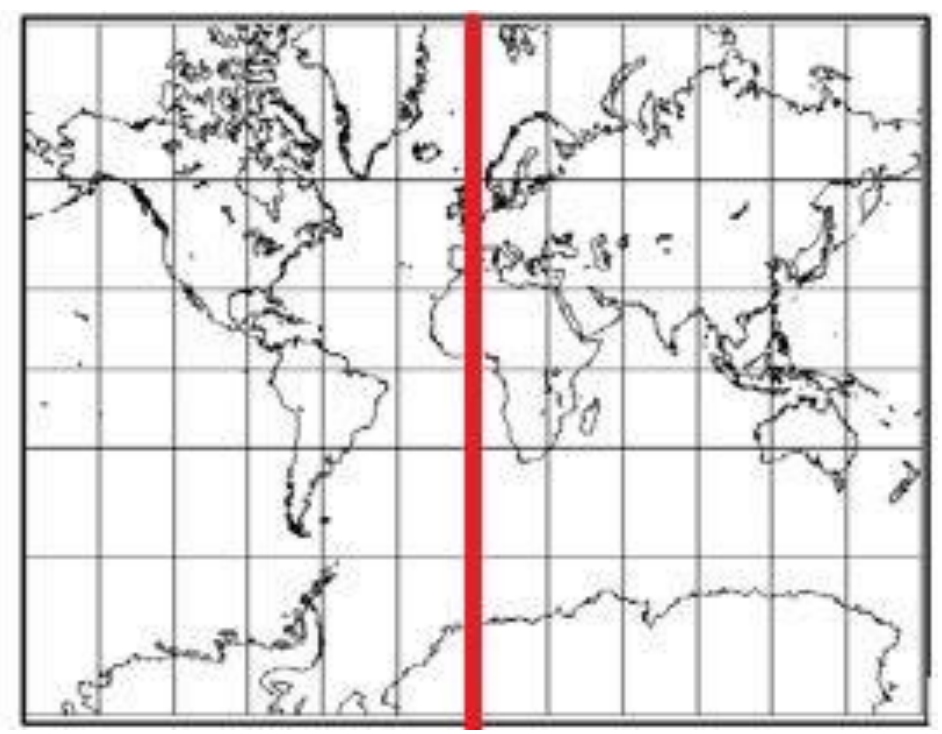

Nada disso significa que o império britânico seja parte de um grupo que exerce poder sobre outro grupo, não se trata de uma relação entre detentores e submetidos, mas de um poder que constitui indivíduos que creem em uma imagem de mundo e os atravessa, passa por ali, toma corpo, de forma capilar, justamente nas "periferias" que ele mesmo criou, em cada localidade, em cada região, como efeitos reais de si mesmo. A questão aqui foi: qual foi a "máquina” que produziu tal acontecimento? Isto é, o que importa aqui é "captar o poder em 
suas extremidades, lá onde ele se torna capilar; captar o poder nas suas formas e instituições mais regionais e locais" (FOUCAULT, 2014, p. 182).

Será a permanência inquestionada da concepção cartográfica hegemônica fundada na projeção Mercator uma simples questão de má interpretação? Tudo leva a crer que o projeto de poder colonial instaura, através de um saber que nos é imposto por meio dos aparelhos escolares, a inquestionável verdade de que o mundo tem essa forma estática e imutável. Assim, cremos, por desapego ao senso crítico, nessa verdade, como quem teme fantasmas e outros modos de existência sabidamente imaginados, pois se trata de uma crença totalmente contraditória, já que simultaneamente ao saber que divide norte e sul, oriente e ocidente, vem os saberes básicos astronômicos, físicos e astrofísicos em relação ao planeta (sua forma e sua relação com o tecido do espaço-tempo). O "erro" induzido é o de não fazermos chocar, não colocarmos em confronto esses dois diferentes tipos de verdade. Cada sujeito, inserido em um programa de verdade e marcado por uma prática discursiva, interioriza a contradição em um misto que cujas partes não são conciliáveis. A questão não é por que não percebemos a contradição, mas como ela se instaura como prática discursiva que instaura e sustenta suas próprias relações de poder.

Portanto, as condições de produção do enunciado, tais como as formações discursivas que o regulam, funcionam de maneira similar à oposição norte e sul, mas muito mais baseado em uma discriminação entre selvagem, bárbaros e civilizados, em que o "centro do mundo" marca a posição dos civilizados; por outro lado, quanto mais periférica sua posição mais "selvagem” se torna o já periférico, bárbaro, segundo a concepção colonial.

\section{Pois é, como?}

Os corpos do sul global, os mesmos corpos das periferias, esses corpos capturados e segregados pelo poder, foram reunidos nas zonas de visibilidade, de enunciabilidade, nas linhas de força e de subjetivação que compõem juntas um dispositivo colonial. Para o poder, os objetos devem ser ideais, enquanto os sujeitos, esses corpos do Sul, domesticados pelo poder, devem ser encarados como emergentes de determinadas formações sociais que os marginalizam e os inferiorizam. Ou seja, eles eram previamente inexistentes, mas o que ocorre é que certas linhas de força que iluminam certas zonas e fazem emergir esses corpos para, a partir de um recorte preciso de cadeias semióticas, propícias para tal, fazer emergir esses sujeitos enquanto objetos semióticos ideais. O que é criado por esse campo de forças são 
as condições de visibilidade e de enunciabilidade, constrói-se a partir de dois regimes de signos: regimes de corpos e regimes de enunciação (DELEUZE, 2005). Isto é, constitui-se uma ordem do discurso, pela qual o poder ilumina ou esconde os corpos (nos regimes dos corpos), assim como obriga a dizer ou a calar (nos regimes de enunciação).

Vivemos sobre as três diferentes formas de captura, se preferir de escravidão, das quais duas ocorrem por meio da linguagem (significação e subjetivação) e uma por meio do corpo (extrato do organismo) que é um regime de sensibilidade. Um uso da linguagem é produção de significação, outro uso da linguagem é produção de sujeitos, a função semiótica da cartografia, com suas divisões e fronteiras, tem essa dupla produção. Em outras palavras, há uma ordem do discurso que produz subjetividade e uma ordem do discurso que produz verdades e universais, dentro de um regime político/econômico hegemônico, os signos se acoplam em função da manutenção do poder desse mesmo regime, nesse caso manifestados na Projeção Mercator. O sujeito só existe pelo assujeitamento, o significante só existe pelo valor dominante de verdade, aqui pautado na invenção de uma verdade geográfica materializada na projeção cartográfica, o significante dominante no mapa é determinado por relações de força operadas pelo poder que atribuem esse valor de dominação.

A problematização das oposições que vimos acima (norte-sul; centro-periferia), sem dúvidas, segue regulando os arranjos geopolíticos e econômicos, como funções políticas e imperativos econômicos.

\section{Referências}

ALIGHIERI, Dante. A divina comédia. Ed. Bilíngue. Tradução Ítalo Eugenio Mauro. São Paulo: Editora 34, 1998.

ANDERSON, Perry. Linhagens do Estado Absolutista. Tradução João Roberto Martins Filho. São Paulo: Brasiliense, 1995.

BOXER, Charles Ralph. Império Colonial Português (1415 - 1825). Lisboa: Edições 70, 1977.

COLOMBO, Cristóvão. Diários da Descoberta da América: as quatro viagens e o testamento. Tradução Milton Persson. Porto Alegre: L\&PM, 1998.

DAVIS, Mike. Planeta favela. Tradução Beatriz Medina. São Paulo: Boitempo, 2006.

DELEUZE, Gilles. Foucault. Tradução Renato Ribeiro. São Paulo: Brasiliense, 2005. 
FERNANDES, Daniel Costa. A política externa da Inglaterra: análise histórica e orientações perenes. Brasília: Fundação Alexandre Gusmão, 2011. Disponível em: $\langle$ http://funag.gov.br/loja/download/812-PolItica_externa_da_inglaterra_A.pdf $>$. Acesso em: 23 mar. 2015.

FOUCAULT, Michel. A arqueologia do saber. Tradução Luiz Felipe Baeta Neves. Rio de Janeiro: Forense Universitária, 1996.

FOUCAULT, Michel. Resumo dos cursos do Collège de France (1970-1982). Tradução Abdrea Daher. Rio de Janeiro: Jorge Zahar, 1997.

FOUCAULT, Michel. Soberania e Disciplina. In: Microfísica do Poder. Tradução e organização Roberto Machado. Rio de Janeiro: Paz e Terra, 2014.

GROS, Fredéric. Caminhar, uma filosofia. Tradução Lília Ledon da Silva. São Paulo: É Realizações, 2011.

HAYES, Diana. Reflections on Slavery. In: CURRAN, Charles E. Change in Official Catholic Moral Teaching. Nova Jérsei: Paulist Press, 1998.

MBEMBE, Achille. Crítica da razão negra. Tradução Sebastião Nascimento. São Paulo: n-1 edições, 2018.

NIETZSCHE, Friedrich. A gaia ciência. Tradução Paulo César de Souza. São Paulo: Companhia das Letras, 2005.

Recebido em: 21 de junho de 2019

Aceito em: 17 de setembro de 2019 